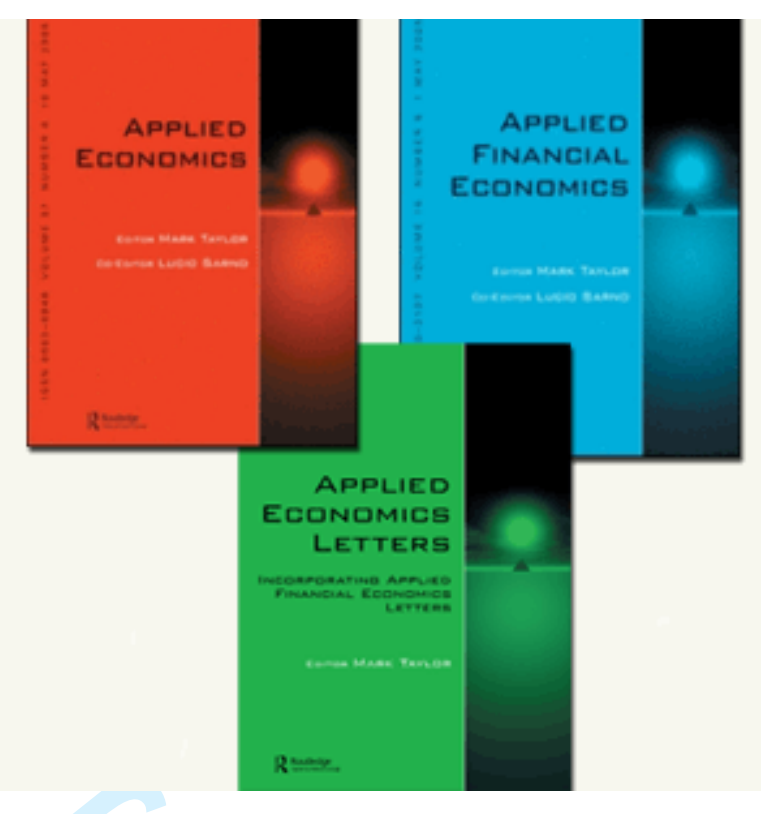

\title{
EMU-related News and Financial Markets in the Czech Republic, Hungary and Poland
}

\begin{tabular}{|c|c|}
\hline Journal: & Applied Economics \\
\hline Manuscript ID: & APE-2009-0128.R1 \\
\hline Journal Selection: & Applied Economics \\
\hline $\begin{array}{r}\text { Date Submitted by the } \\
\text { Author: }\end{array}$ & 05-Nov-2010 \\
\hline Complete List of Authors: & $\begin{array}{l}\text { Hayo, Bernd; Philipps-University Marburg, Faculty of Business and } \\
\text { Economics } \\
\text { Buettner, David; Philipps-University Marburg }\end{array}$ \\
\hline JEL Code: & $\begin{array}{l}\text { F30 - General < F3 - International Finance < F - International } \\
\text { Economics, G12 - Asset Pricing < G1 - General Financial Markets < } \\
\text { G - Financial Economics, G15 - International Financial Markets < G1 } \\
\text { - General Financial Markets < G - Financial Economics }\end{array}$ \\
\hline Keywords: & $\begin{array}{l}\text { Financial markets, CEEC-3, political news, macroeconomic shocks, } \\
\text { European Monetary Union }\end{array}$ \\
\hline
\end{tabular}

\section{SCHOLARONE' Manuscripts}




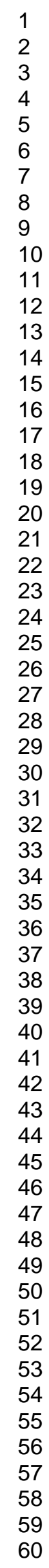

14

15

16

18

19

20

22

24

26

27

29

30

32

33

34

35

36

39

40

41

42

44

45

46

47

48

49

50

52

53

54

56

57

58

60

Editorial Office, Dept of Economics, Warwick University, Coventry CV4 7AL, UK 


\title{
EMU-related news and financial markets in the Czech Republic, Hungary and Poland
}

\author{
D. Büttner ${ }^{\mathrm{a}}$ and B. Hayo ${ }^{\mathrm{a}, *}$
}

a Philipps-University, D-35032 Marburg, Germany

* Corresponding author. E-mail: hayo@wiwi.uni-marburg.de 


\begin{abstract}
We analyse the impact of news on five financial markets in the Czech Republic, Hungary and Poland using a newly constructed data set in a GARCH framework. Macroeconomic shocks (on GDP, inflation rate, current account and trade balance) are constructed as deviations from expected values. EMU-related political and fiscal news is captured as news dummies. Macroeconomic shocks significantly affect short-term interest rates and, to a lesser extent, other financial variables. Political and fiscal news has an impact on longterm bond yields and exchange rates. News displayed prominently in our media sources has a greater impact on financial markets than other news and, in addition, the sources of news themselves matter. We also discover asymmetric effects of news within markets. Finally, using a pooled GARCH model we find that macroeconomic shocks have the strongest impact on financial markets in Hungary, while political news has the largest influence in both Hungary and Poland.
\end{abstract}

JEL: G12, G15, F30. 


\section{Introduction}

An examination of European financial markets in the second half of the 1990s reveals that as soon as markets believed a country would be fully accepted into the European Economic and Monetary Union (EMU), long-term interest rate spreads versus Germany decreased rapidly (Figure 1). The reason for this convergence is that exchange rate risk is nonexistent in a monetary union and that less stability minded countries could gain monetary credibility by joining the EMU. Such an adjustment also affects foreign exchange rates and stock markets as foreign investors seek to buy assets in the country in question before a full convergence of interest rates is achieved.

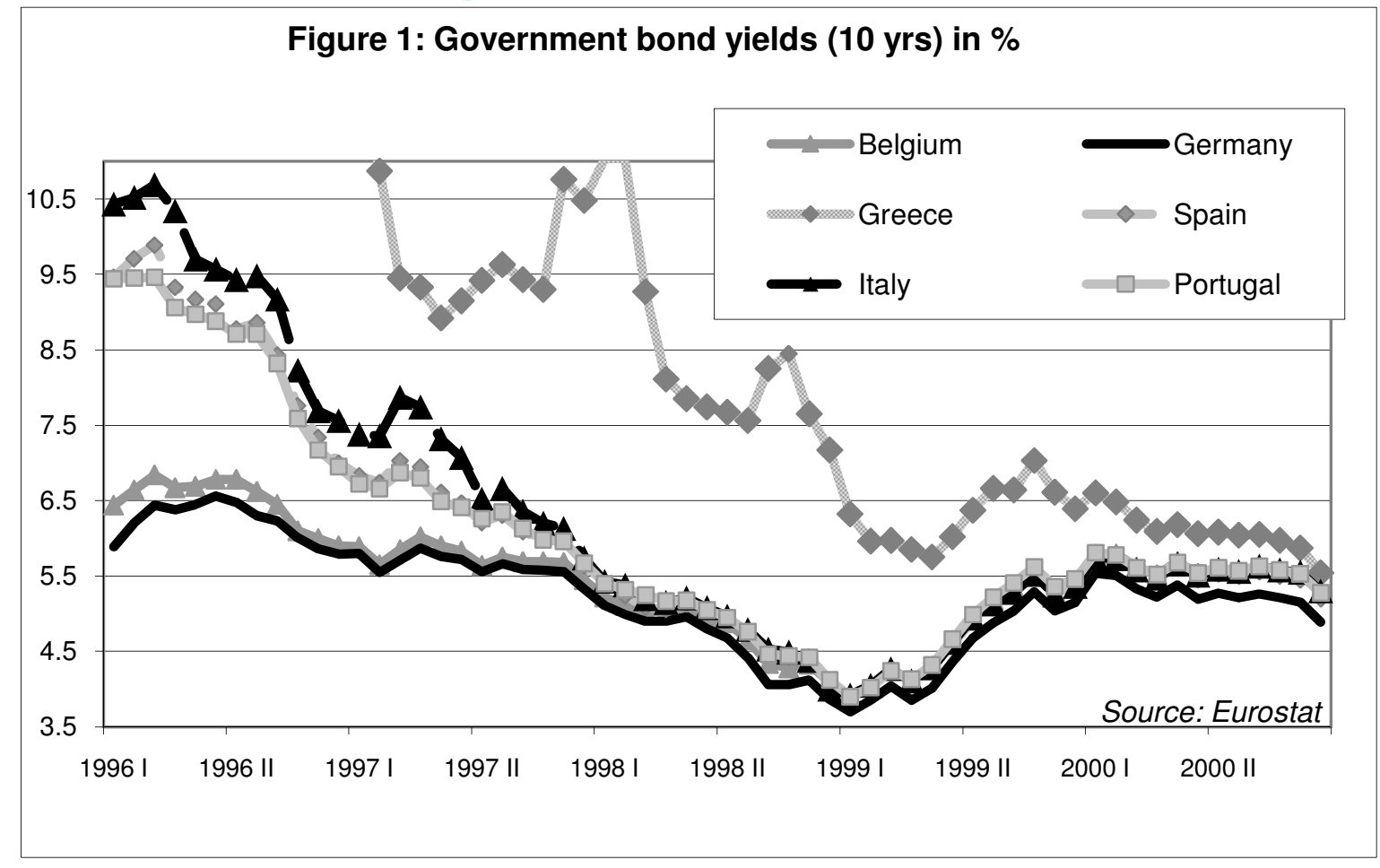

This raises the question of what determines expectations of financial market agents with regard to the euro adoption date of a specific country. What kinds of new information would make financial markets shift their assessment? It seems plausible that news concerning the fulfilment of the Maastricht criteria, the willingness of the government to 
introduce the euro, the judgement of international institutions (e.g. the EU or the IMF) or of market analysts on the readiness of the country to adopt the euro as well as macroeconomic conditions might play a role. The three largest new EU member states, the Czech Republic, Poland and Hungary (CEEC-3) envisage a relatively late euro adoption. ${ }^{1}$ However, over our sample period 2004 to 2006, the three countries faced very different challenges. ${ }^{2}$ The Czech Republic has almost achieved convergence with the 'old' EU-15 in terms of interest and inflation rates and, to some extent, of per capita income as well. The Czech crown is free floating without major turbulences, the current account deficit is manageable and the trade balance turned into a surplus during the observation period. ${ }^{3}$ The only area of concern is that of fiscal policy (deficit of 3.5\% of Gross Domestic Product (GDP) in 2006), where some significant (and most probably unpopular) adjustments are needed in order to ensure a fulfilment of the Maastricht convergence criteria as a precondition for entry into EMU.

Hungary operates an Exchange Rate Mechanism II style exchange rate regime with $\pm 15 \%$ fluctuation bands around a central parity. ${ }^{4}$ The macroeconomic policy-mix (high fiscal deficit and large current account deficit) has not been suitable for this kind of arrangement. Consequently, the Hungarian forint came under pressure several times when foreign exchange markets lost faith in the Hungarian economy and were uncertain about the course of Hungarian economic and monetary policy. ${ }^{5}$ During the observation period the inflation rate was around 3.5-6.8\%, well above the Maastricht criterion. In 2006, the fiscal

\footnotetext{
${ }^{1}$ As of July 2008, none of the CEEC-3 has entered the ERM II (Exchange Rate Mechanism II). The ERM II, which is sometimes referred to as the 'ante-chamber of euro adoption', is a hybrid exchange rate regime, where currencies are allowed to fluctuate by $15 \%$ around a central parity against the euro. Before adopting the euro, a country has to remain in the ERM II for 2 years.

${ }^{2}$ The figures on the CEEC-3 are taken from: European Commission (2006).

${ }^{3}$ The Czech National Bank intervenes occasionally to reduce the volatility of the exchange rate. There is no explicit exchange rate target. For the exchange rate arrangements of the CEEC-3, see IMF (2006). For a more thorough treatment of exchange rate policy in the CEEC-3 (and Slovakia), see Kočenda and Valachy (2006).

${ }^{4}$ This exchange rate regime was replaced by a free float on 26 February 2008.

${ }^{5}$ For instance, in January 2003, the Hungarian central bank (MNB) had to defend the upper band of the exchange rate and later in the year the lower band, resulting in massive interest rate hikes.
} 
deficit increased to $9.2 \%$ of GDP and the general government debt reached $66 \%$ of GDP. Thus, currently, Hungary fulfils none of the Maastricht criteria.

Poland also initially faced problems containing fiscal expenditures, partly due to political instability (minority governments, seven finance ministers since 2004), but managed to bring the deficit down to $3.9 \%$ of GDP in 2006. The current account deficit is lower than in Hungary and the free-floating Polish zloty poses less of a problem. Applying an inflation target of $2.5 \%$, the Polish central bank, the NBP, kept inflation under control. ${ }^{6}$

In this paper, we examine the impact of news related to the possibility of a euro introduction on financial markets in the CEEC-3 empirically using daily newsletters from Interfax. Our main hypothesis is that positive news - i.e. news making an early adoption of the euro more likely - should reduce the interest rate spread versus the euro area, increase share prices and strengthen the local currency. We also examine the effect of macroeconomic news, taking into consideration the expectations of market participants. The news component here is defined by the actual outcome of a macroeconomic indicator less its expected value derived from consensus forecasts.

Although this approach is partly subjective, its advantage in comparison to studies focusing solely on macroeconomic news (Hanousek at al. 2009) is the inclusion of political events (e.g. Baig et al. 2006). The creation of the EMU was partly driven by political considerations and therefore such news can be expected to be of particular importance for financial markets in the CEEC-3 during the run-up towards adopting the euro. News is included as dummies (political news) or shocks (macroeconomic news) in models explaining changes in the yields of 10-year government bonds (versus EMU counterparts), 3 and 12 month interbank interest rates, exchange rates versus the euro and the performance of the stock markets. The estimations are conducted using GARCH (Generalized Autoregressive Conditional Heteroscedasticity) models (where applicable,

\footnotetext{
${ }^{6}$ The inflation rate fluctuated between $3.6 \%$ in 2004 and $1.3 \%$ in 2006.
} 
otherwise OLS), thereby accounting for the specific nature of financial data, i.e. timevarying volatility and volatility clustering.

Within this methodological framework, we first investigate the impact of news across different financial markets in our sample countries. Second, we study whether the prominence of a particular news item in the press reports matters, with the conjecture that highly prominent news has a notable effect on markets while other news is ignored. Third, we analyse whether the source of a particular news item plays a role as some sources are perceived as more credible than others. Fourth, we search for asymmetric effects of positive and negative news on financial markets. Fifth, we investigate whether news tends to have an effect on financial markets' volatility. Finally, using a pooled GARCH model, we test for asymmetric effects of news across countries. Given the different economic developments of the CEEC-3 outlined above, the characteristics of a country may determine which sort of news is particularly important for each of the financial markets.

The article proceeds as follows: In section II we give a brief overview of the existing literature on news and financial markets. In section III we describe the construction of the news events and the data sources. Section IV discusses the transmission channels of news on financial markets and section $\mathrm{V}$ explicates the econometric methodology. In section VI we present our results and section VII concludes.

\section{Related Literature and Contribution of this Article}

While the effects of news are intensively analysed for well-developed financial markets, there are few studies on emerging markets involving Eastern European countries, and, moreover, these tend to concentrate on periods of market turmoil. ${ }^{7}$

\footnotetext{
${ }^{7}$ Onder and Simga-Mugan (2006) and Andritzky et al. (2007) summarize the relevant literature on the effects of news for both mature and emerging financial markets.
} 
Hanousek and Filer (2000) study the degree of efficiency of the recently established stock markets in the Visegrad countries (CEEC-3 and Slovakia). Using monthly data, they show that lagged values of a set of economic variables have an impact on stock markets in Poland and Hungary. For the Czech Republic, they find neither contemporaneous nor lagged connections with the stock market. Therefore, there is evidence of a lack of efficiency of stock markets in the CEEC-3, at least during their first years of existence.

Hayo and Kutan (2005a) examine the reaction of financial markets on IMF announcements in six emerging countries during the period 1997-1999. They find that IMF news has a significant and economically relevant impact on stock returns. While foreign exchange markets are only affected by negative news, bond returns do not react to IMF news at all. They cannot detect any impact of IMF news on markets' volatility. Focusing on Russia, Hayo and Kutan (2005b) analyse the impact of different types of political news. Their findings suggest that financial markets do not react to political news per se. ${ }^{8}$

Andritzky et al. (2007) study the effect of macroeconomic announcements on bond spreads of a group of emerging markets. They discover that domestic news has a limited impact, for instance changing assessments by rating agencies while changes in US interest rates are highly significant. The effects of news on volatility depend on the type of news. While domestic macroeconomic announcements tend to reduce volatility by reducing uncertainty, rating actions have the opposite effect as investors adjust their portfolios to this new information.

Hanousek et al. (2009) investigate the reaction of asset prices in the Czech Republic, Hungary and Poland to local, euro area and US macroeconomic news. Their study uses intraday data and covers the period from mid-2003 until the end of 2006. They discover spillover effects to CEEC-3 stock markets both from the EU and the US.

\footnotetext{
${ }^{8}$ In a recent study, Chaney (2008) evaluates political events concerning Iraq using bond spreads versus US bonds.
} 
Moreover, they find an impact of EU news on the Hungarian and, to a lesser extent, Polish markets. The Czech market is rather affected by US news; however, local news does not have a noticeable influence. The authors attribute this result to the timing of macroeconomic news releases: most announcements are made before the markets open. Hence a study using intraday data is unlikely to discover any effects as the news is absorbed by investors before the market opens. ${ }^{9}$

Our approach uses daily data and therefore should be able to capture the effects of news announcements made before the markets open. Evans and Lyons (2008) show in the context of foreign exchange markets that three sources of price movements are relevant at intradaily and daily frequencies: the direct effect of macroeconomic news, the indirect effect of macroeconomic news through a reaction of order flows and order flows unrelated to public news. In our approach, we can only capture the first of these effects.

We focus on the CEEC-3 and take macroeconomic shocks as well as political news into consideration. These three emerging countries did not face a larger economic crisis during the observation period but are interesting for other reasons. First, they are among the most advanced of transition countries. Second, membership of the EU and the adoption of the acquis communautaire stimulate an inflow of foreign capital that spurs nominal and real convergence. Third, the prospect of euro adoption drives nominal convergence. When the adoption date draws closer, interest rates converge to euro area levels. Foreign investors accelerate this process by transferring large amounts of portfolio capital into the euro candidate countries to profit from the convergence of interest rates (see Luengnaruemitchai and Schadler, 2007). Fourth, entry into the EMU is heavily influenced

\footnotetext{
${ }^{9}$ Moreover, the authors do not include the first 15 and last 5 minutes of a trading day as those periods are associated with excess volatility. This practically excludes any effects of news published when markets are closed.
} 
by political considerations. Hence, political news related to euro adoption is of particular interest for financial markets in these countries. ${ }^{10}$

\section{Data and Construction of News}

Table A1 in the Appendix presents the descriptive statistics of the financial market variables. They are computed as daily changes of euro area/CEEC-3 interest rate differentials for 10 year government bonds, daily changes of 3 month and 12 month interbank interest rates and the first differences of exchange rates (CEEC-3/euro) and CEEC-3 stock indices in logarithms, respectively. These transformations remove the unit roots from the series while preserving a useful economic interpretation of the variables. ${ }^{11}$

The samples consist of 717 to 726 daily observations over the period 2004 to 2006, depending on the number of trading days. Most financial market time series display excess kurtosis and skewness, indicating nonnormal distributions and the presence of ARCH. The daily changes of the interest rate differentials are characterized by negative means, reflecting the convergence process vis-à-vis the euro area. An exception is the Czech Republic, where short-term interest rates are already at, or even below, the euro area level. For Hungary we observe the highest variances in financial markets of the CEEC-3, which might be due to relatively high interest rates and uncertainty arising from the 'twin deficit'. However, its exchange rate is an exception, as it is less volatile than that of Poland, probably reflecting the differences in the foreign exchange regimes mentioned above.

\footnotetext{
${ }^{10}$ Another reason is that in these relatively young democracies, the political spectrum is far from settled. Changes in government are more frequent than in Western Europe and political parties are less oriented towards the political centre. Thus changes in governments have a larger impact on financial markets as they entail larger swings in the policy stance.

${ }^{11}$ We performed Augmented Dickey-Fuller tests and all but one time series (3 month Hungarian interest rates) had unit roots. The results are available upon request.
} 
As control variables we include the respective international counterparts (e.g. for the 3 month interbank interest rates we control for movements of euro area and US interest rates of the same maturity), interest rates of other maturities, exchange rates, stock market indices and changes in the EMBI ${ }^{12}$ to capture general swings in investors' risk perception of emerging markets. We also control for central bank decisions on interest rates and evaluate whether these decisions are surprises for financial markets.

Macroeconomic shocks are constructed using the absolute deviations of actual (usually preliminary) publications of statistical offices and central banks from consensus forecasts. ${ }^{13}$ Here we look at shocks to GDP growth rates $(G D P)$, inflation rates $(I N F)$ and the balance of payments (current account $(C A)$ and/or trade balance shocks $(T B)$ ). Owing to data limitations, in some cases we can only construct shock variables on $C A$ and $T B$ announcements. Partly to compensate for that, we also include dummy variables capturing surprising - according to our news sources - balance of payments announcements (CASU/TBSU), for which there are no corresponding consensus forecasts. Thus, we have to interpret the estimates based on these data with some caution. However, all our main findings and the conclusions remain valid when we exclude the $C A$ and $T B$ announcements from the models.

Political news dummies are constructed using the Interfax Business Reports for the CEEC-3. Over the observation period these daily newsletters contained more than 20,000 pages, consisting of self-written articles and summaries of national newspaper reports. For this study, we selected only those events or decisions that have a lasting effect and at least

\footnotetext{
${ }^{12}$ The Emerging Market Bond Index is calculated by JP Morgan and captures the spread between the yield on a dollar-denominated sovereign bond and the yield of a comparable bond issued by the US Treasury.

${ }^{13}$ See Tables A2 and A3 in the Appendix. Using a methodology applied by, inter alia, Joyce and Read (1999), Gavin and Mandal (2001) as well as Gravelle and Moessner (2001), we confirm that our consensus forecasts are generally unbiased and efficient. That is, forecast errors are mean zero uncorrelated with their own past and future values as well as with actual and forecasted past and future values. Detailed results are available upon request.

Note that for current account and trade balance data, the consensus forecasts are taken from the Interfax Business Reports. The base of these consensus forecasts is not consistent and therefore results should be treated with caution.
} 
an indirect impact on the timing and/or likelihood of euro adoption. Relevant information is categorized into positive and negative fiscal (Fiscal) and political (Political) news. We use various search procedures to identify potentially relevant passages in the electronic newsletters. Each of these passages was checked and interpreted independently by two people. In case of differences in the categorisation, we sought another opinion to ensure high reliability of the coding.

\section{Transmission Channels of News on Financial Markets}

The CEEC-3 are small open economies and, in addition to the direct effects of political or macroeconomic news on interest rates and stocks, there is a noticeable indirect effect via the exchange rate channel. Any news causing the exchange rate to depreciate will also cause interest rates to rise and stock prices to fall as foreign investors withdraw their portfolio investments. ${ }^{14}$

GDP growth surprises may affect financial markets through two main channels. ${ }^{15}$ On the one hand, a larger than expected output growth rate suggests higher earnings for firms in the future and raises stock market prices. Furthermore, an unexpected increase in real activity improves public finances, thus lessening the need for government bond issuance and increasing the likelihood of fulfilment of the fiscal deficit convergence criterion. On the other hand, shocks pushing output above its trend may induce the central bank to raise short-term interest rates, triggering an appreciation of the exchange rate and a reduction of stock market prices.

\footnotetext{
${ }^{14}$ For the CEEC-3 this effect might be even larger as the so-called 'convergence play' increases the inflow of portfolio capital.

${ }^{15}$ The following section discusses positive macroeconomic shocks, i.e. actual figures are above expected values and positive fiscal and political news. In the case of negative shocks and news, the effects outlined take the opposite direction.
} 
Inflation shocks tend to raise short-term interest rates, which can cause an exchange rate appreciation and a stock market downturn. The relationship with longer-term interest rates is less clear-cut since other aspects also play a role, such as default and depreciation risks. ${ }^{16}$ If the inflation shock is believed to be persistent, a depreciation of the local currency due to purchasing power parity adjustments may also be observed.

A third group of macroeconomic announcements considered in this article concerns the external balance. The unexpected components of current account and/or (depending on availability) trade balance figures are incorporated in the model. In general, the economic catching-up process is often accompanied by external deficits as the savings of transition economies are insufficient to finance their investment needs. Under these conditions, financial markets can be highly sensitive to external balance indicators. An unsustainable international debt position of a country may lead to a reversal of capital flows, thereby causing a currency crisis and - should external debt be mainly denominated in foreign currency - also a debt crisis. Therefore, an improvement in the external balance should strengthen the confidence of international investors and consequently lead to an appreciation of the local currency. Furthermore, investors may start buying assets, such as equity or government bonds, causing stock market indices to rise and interest rates to fall.

A further potential transmission channel of external balance news is related to monetary policy. Central banks react to changes in macroeconomic conditions, in particular those related to inflation and the state of the business cycle. They may also be influenced by balance of payments news - especially if the trade or current account deficit is large. For instance, negative current account shocks may trigger a fall in central banks' main refinancing rates with the aim of causing a depreciation of the domestic currency and an improvement of the trade balance. Under rational expectations, financial market actors

\footnotetext{
${ }^{16}$ Pearce and Roley (1985) discuss other channels of how shocks to the inflation rate may affect stock markets.
} 
would anticipate such a reaction of the central bank and adjust their portfolios accordingly. ${ }^{17}$

Fiscal policy affects financial markets in several ways. A fiscal expansion leads to larger financing needs of the government sector and to higher yields on the fixed income assets as their supply increases. Furthermore, financial markets may react sensitively to fiscal news in countries such as Hungary, where fiscal sustainability is in doubt. A deterioration of the fiscal situation may cause a capital outflow that leads to negative effects on all domestic financial markets. Finally, as outlined in the Introduction, government deficits and debt levels are crucial for the introduction of the euro. As a result 'bad' fiscal news might delay euro adoption and, consequently, also interest rate convergence.

Political news may have similar effects. An announcement (for instance by the government or the European Commission) which directly implies a delay of euro adoption has a negative impact on fixed income assets, foreign exchange markets and the stock exchange. Political news also includes election results or a government crisis as these events might brighten (or worsen) the economic outlook of the respective country and thereby trigger portfolio adjustments.

\section{Econometric Methodology and Estimation Issues}

As outlined in the data section, our financial market series exhibit volatility clustering and nonnormal distributions. To deal with these phenomena we use GARCH models in alternative specifications. ${ }^{18}$ Starting with the GARCH model proposed by Bollerslev (1986) we employ several extensions. To test whether risk is priced in financial markets

\footnotetext{
${ }^{17}$ However, in the medium term, this policy would also increase output and along with this imports.

18 Otherwise, we use OLS and add a maximum of 10 dummies capturing outliers to approximate a normal distribution. These dummies do not noticeably affect the estimates or significance of our variables of interest.
} 
we include the conditional variance $h_{t}$ in the mean equation (Engle et al. 1987). Furthermore, we test whether innovations have asymmetric effects, i.e. if the impact of negative forecast errors on the conditional volatility differs from positive ones (Engle and $\mathrm{Ng}, 1993$ ). If asymmetry (as captured by $\kappa_{1}$ in equation (1) below) is not centred around zero, we take this into account by using asymmetry thresholds $\left(\kappa_{2}\right)$ (Glosten et al., 1993). Thus, in the general model we apply an Asymmetric Threshold GARCH-in-Mean model (ATGARCHM). ${ }^{19}$ To address deviations from normality we allow the error term to be tdistributed with $\mathrm{v}$ degrees of freedom (Bollerslev, 1987). There may be differences in the speed of news affecting financial markets, either because of information leaks or processing delays. To account for this, we look at a time window of three days, i.e. yesterday (lag), today and tomorrow (lead). The starting model of our analysis is given in equation (1):

$$
\begin{aligned}
& \text { Returns }_{t}=c+\sum_{r=1}^{4} \delta_{r} \text { Returns }_{\mathrm{t}-\mathrm{r}}+\sum_{r=1}^{4} \gamma_{r} \text { Control Variables }{ }_{\mathrm{t}-\mathrm{r}} \\
& +\sum_{r=-1}^{1} \phi_{r} \text { Macroeconomic News Variables }_{\mathrm{t}-\mathrm{r}} \\
& +\sum_{\mathrm{r}=-1}^{1} \varphi_{\mathrm{r}} \text { Political News Dummies }_{\mathrm{t}-\mathrm{r}}+\eta \mathrm{h}_{\mathrm{t}}+\mathrm{u}_{\mathrm{t}} \text {, }
\end{aligned}
$$

Note that $\mathrm{c}, \alpha_{0}, \alpha_{1}, \beta, \delta, \phi, \varphi, \gamma, \eta, \kappa_{1}$ and $\kappa_{2}$ are parameters or vectors of parameters, $\tau$ is an indicator function and $\varepsilon_{\mathrm{t}} \mathrm{t}$-distributed with $\mathrm{v}$ degrees of freedom.

\footnotetext{
${ }^{19}$ Depending on the outcome of the general-to-specific modelling process, in the reduced models we also apply OLS, Asymmetric GARCH (AGARCH), GARCH-in-Mean (GARCHM), Asymmetric GARCH-inMean (AGARCHM) models. See Tables 1, 2, 3 and 6.
} 
Beginning with (1), we arrive at a more parsimonious statistical representation of the control variables by using a consistent general-to-specific modelling approach (Hendry, 1995). Given the nonnormality of our time series, we employ robust standard errors as developed by Bollerslev and Wooldridge (1992), in addition to a t-distribution with up to 6 degrees of freedom that provides a better fit to our data. ${ }^{20}$

The estimation results are presented in Tables 1 to 3 . Given the large number of models, we can only discuss some of the main features here. ${ }^{21}$ In several models, the parameters for asymmetry and threshold asymmetry are significant, implying that (in our models) positive forecast errors have a greater impact on conditional volatility than do negative forecast errors. ${ }^{22}$ Finally, in four models the conditional variance significantly enters the mean equation which could be interpreted as risk priced in the market. However, the respective coefficients have a negative sign, which means the interest rate (the exchange rate) is lower (appreciates) as a result of increased risk. Hence, another interpretation is more likely. It is possible that when financial market participants gather new (positive) information on the respective country, the interest rate decreases (the exchange rate appreciates) and as markets adjust to this new information, volatility increases.

While the GARCH models capture the ARCH effects satisfactorily, in a few instances weak autocorrelation remains in spite of adding a rich dynamic structure. In some cases, we do not detect any ARCH effects and estimate equation (1) without considering the conditional variance to maximize estimation efficiency. In almost all cases (except for

\footnotetext{
${ }^{20}$ This applies to the GARCH specification.

${ }^{21}$ In a few specifications, we had to ensure stationarity of the conditional variance by imposing the restriction $\alpha_{1}+\beta_{1} \leq 1$, leaving some of the parameters insignificant. These findings may also indicate the presence of integrated GARCH processes (see Nelson 1990). On 6 February 2004, the Czech 3 month interest rate increased by almost 50 basis points without any apparent reason and on 14 January 2004 bond yields rose by 40 basis points in Poland. Since the convergence algorithms of our GARCH specifications were seriously affected by these outliers, we added additional impulse dummies for these days.

${ }^{22}$ Note that in one case ( 3 month interbank interest rates in Poland) the asymmetry term is insignificant. It remains in the model as it cannot be eliminated in a consistent testing-down process.
} 
one) the RESET test is insignificant at the $10 \%$ level, which indicates that the linear OLS specification is acceptable. ${ }^{23}$

In 11 of 15 models one or several of the lagged dependent variables are significant. This is a violation of market efficiency as markets are assumed to process all available information and thus market returns should not be predictable by past values. However, to some extent this predictability of returns may also be due to transaction costs and, given the size of financial markets in these emerging economies, it could also be a sign of low liquidity and missing depth of these markets.

\section{Analysing the Effects on Financial Markets' Returns}

The estimation results of the basic models are summarized in Tables 1-3, concentrating on our variables of interest (omitted information available upon request). In general, our hypotheses about the effect of news are confirmed by the analyses. Among the macroeconomic shocks, those related to GDP and inflation are consistently significant, while shocks originating from the balance of payments generate some surprising signs. For instance, positive (negative) surprises of current account announcements drive 3 and 12 month interest up (down). On the one hand, this seems to support the hypothesis stated in section IV, namely that monetary policy might be used to stabilize the balance of payments. On the other hand, the reaction of Hungarian short-term interest rates on trade

\footnotetext{
${ }^{23}$ Results omitted but available upon request. We also do not find any signs for heteroscedasticity in the OLS models. In some instances, we find evidence of nonnormality. We are able to remove this nonnormality by including dummy variables to capture a small number of outliers and can show that our estimation results are robust to these changes. Note that the estimates for the Bond spread of the Czech Republic show mild signs of ARCH in the final model. Since these signs appeared only after removing nonnormality, we think that these ARCH effects are spurious and we choose to stick to the presented OLS model for reasons of estimation efficiency. In any case, the presented parameter estimates would not change in a noteworthy way.
} 
Table 1: Czech Republic: Results of the basic model

\begin{tabular}{|c|c|c|c|c|c|c|}
\hline & & $3 \mathrm{~m}$ & $12 \mathrm{~m}$ & Bonds & Crown/euro & Stock market \\
\hline & & GARCH & GARCH & OLS & OLS & GARCHM \\
\hline & Cases & Coeff. & Coeff. & Coeff. & Coeff. & Coeff. \\
\hline $\begin{array}{l}\alpha_{0} \\
\alpha_{1} \\
\beta_{0} \\
\text { student-t } \\
h_{t} \\
\end{array}$ & & $\begin{array}{l}3.8 \mathrm{E}-07 \\
0.37 \\
0.63^{\star \star \star} \\
2.21\end{array}$ & $\begin{array}{l}0.00044 \\
0.73 \\
0.27 \\
2.10\end{array}$ & & & $\begin{array}{l}6.9 \mathrm{E}-06^{\star \star} \\
0.19^{\star \star \star \star} \\
0.81^{\star \star \star} \\
3.11 \\
-3.69^{\star \star \star} \\
\end{array}$ \\
\hline $\begin{array}{l}\text { GDP } \\
\text { GDP lag } \\
\text { INF+ } \\
\text { INF+ lag } \\
\text { INF- } \\
\text { INF- lag } \\
\text { CASU+ lead } \\
\text { CA+ lead } \\
\text { CA+ lag } \\
\text { CA- lead } \\
\text { CA- lag } \\
\text { TBSU+ lead } \\
\text { TBSU+ } \\
\text { TBSU+ lag } \\
\text { TBSU- } \\
\text { TB+ } \\
\text { TB+ lag } \\
\text { TB- }\end{array}$ & $\begin{array}{r}10 \\
10 \\
14 \\
14 \\
17 \\
17 \\
12 \\
7 \\
7 \\
8 \\
8 \\
18 \\
18 \\
18 \\
11 \\
10 \\
10 \\
9\end{array}$ & $\begin{array}{c}0.0002^{\star} \\
0.02^{\star \star \star} \\
-0.01^{\star \star \star} \\
-0.01^{\star \star \star} \\
0.004^{\star \star \star} \\
\end{array}$ & $\begin{array}{l}-0.01^{*} \\
-0.01^{* \star \star} \\
-0.002^{* * *} \\
-0.001^{* *} \\
0.004^{* \star}\end{array}$ & $\begin{array}{l}-0.02^{\star} \\
0.005^{\star *} \\
0.01^{\star}\end{array}$ & $\begin{array}{l}-0.002^{\star} \\
-0.003^{\star \star \star}\end{array}$ & $\begin{array}{l}-0.003^{\star} \\
-0.01^{\star \star} \\
\\
-0.01^{\star \star \star} \\
-0.001^{\star \star} \\
0.001^{\star \star}\end{array}$ \\
\hline $\begin{array}{l}\text { Fiscal+ } \\
\text { Fiscal+ lag } \\
\text { Fiscal- } \\
\text { Political+ } \\
\text { Political+ lag } \\
\text { Political- }\end{array}$ & $\begin{array}{r}10 \\
10 \\
8 \\
7 \\
7 \\
16\end{array}$ & & & $\begin{array}{l}-0.017^{\star *} \\
-0.016^{\star}\end{array}$ & $\begin{array}{l}0.002^{* *} \\
0.002^{* *} \\
0.001^{*}\end{array}$ & $\begin{array}{c}0.005^{\star \star *} \\
-0.003^{\star} \\
-0.005^{\star \star}\end{array}$ \\
\hline \multicolumn{2}{|c|}{ No. of observations } & 712 & 712 & 712 & 712 & 712 \\
\hline \multicolumn{2}{|c|}{ Log-Likelihood } & 2435.34 & 2110.47 & 1600.42 & 3206.94 & 2348.64 \\
\hline \multicolumn{2}{|c|}{ Normality test $\left(\mathrm{Chi}^{2}(2)\right)$} & $593.18^{\star \star \star}$ & $1874^{\star \star \star}$ & 3.27 & 3.56 & $184.4^{\star \star \star}$ \\
\hline \multicolumn{2}{|c|}{ ARCH 1-1 test } & $F(1,653)=0.06$ & $F(1,651)=0.32$ & $F(1,645)=3.66^{*}$ & $F(1,653)=2.57$ & $F(1,648)=1.38$ \\
\hline \multicolumn{2}{|l|}{ ARCH 1-2 test } & $\mathrm{F}(2,651)=0.53$ & $F(2,649)=0.28$ & $\mathrm{~F}(2,643)=2.78^{*}$ & $F(2,651)=1.29$ & $F(2,646)=0.68$ \\
\hline \multicolumn{2}{|l|}{ Portmanteau test } & $\operatorname{Chi}^{2}(25)=35.5^{*}$ & $\operatorname{Chi}^{2}(24)=41.7^{* *}$ & $\operatorname{Chi}^{2}(26)=43.3^{\star *}$ & $\operatorname{Chi}^{2}(26)=30.95$ & $\operatorname{Chi}^{2}(26)=25.9$ \\
\hline
\end{tabular}

Notes: $* * *, * *$, and $*$ indicate significance at a $1 \%, 5 \%$ and $10 \%$ level.

Abbreviations: GARCHM - GARCH-in-Mean, INF - inflation shock, CA -current account, TB - trade balance, Fiscal - fiscal news, Political - political news, +/- indicate higher/lower than expected outcomes for macroeconomic variables and positive/negative surprises for political/fiscal news. SU are surprise components of TB and CA shocks where available. Otherwise CA/TB are captured by dummies. See section III for details.

Bonds: CASU- and CASU- lag have been excluded due to offsetting effects $\left(\mathrm{Chi}^{2}(1)=0.01\right)$.

CA- and CA- lag have been excluded due to offsetting effects $\left(\mathrm{Chi}^{2}(1)=0.04\right)$. 
Table 2: Hungary: Results of the basic model

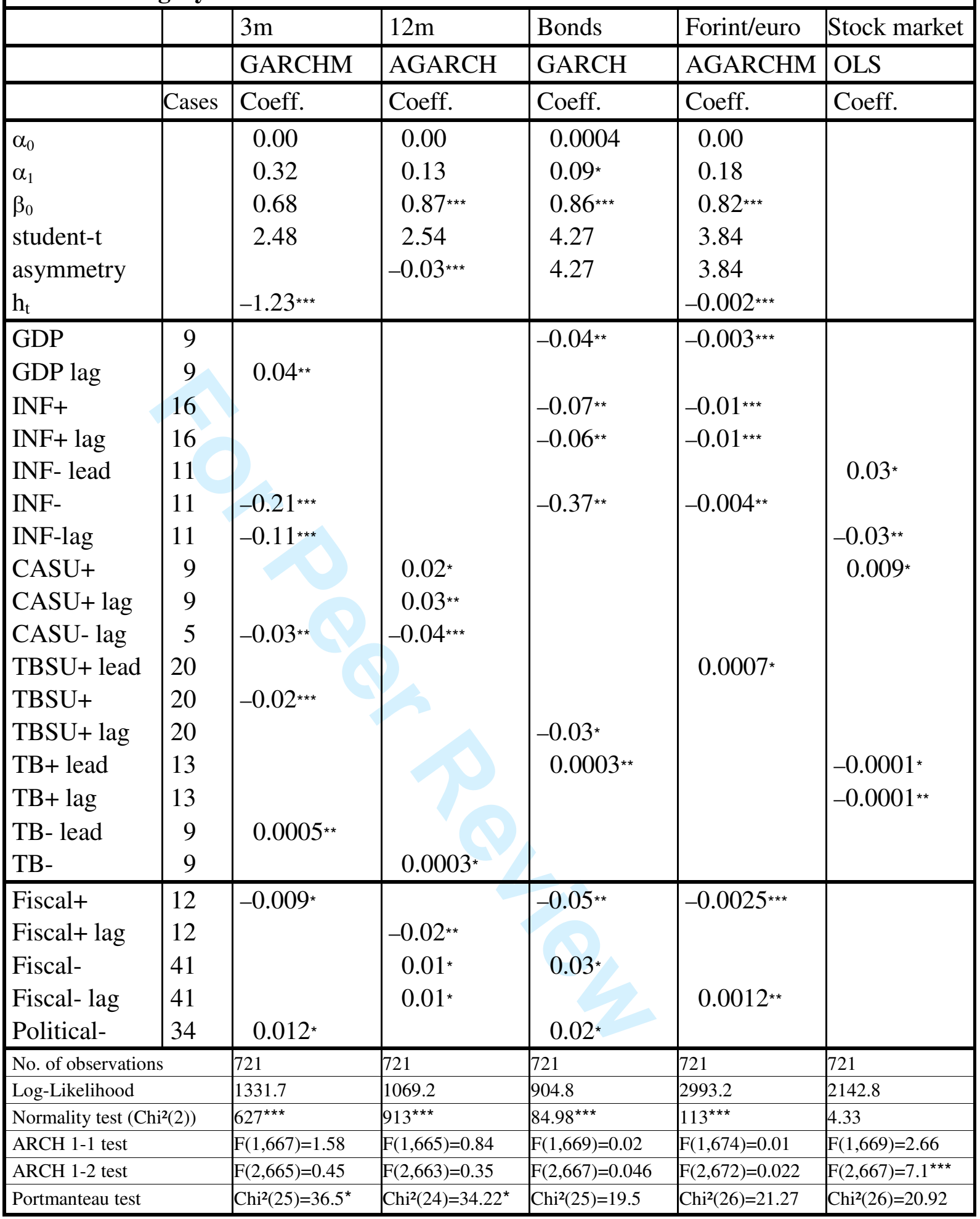

Notes: $* * *, * *, \quad$ and $*$ indicate significance at a $1 \%, 5 \%$ and $10 \%$ level. Abbreviations: GARCHM - GARCH-in-Mean, AGARCH - Asymmetric GARCH, AGARCHM Asymmetric GARCH-in-Mean, INF - inflation shock, CA - current account, TB - trade balance, Fiscal fiscal news, Political - political news, +/- indicate higher/lower than expected outcomes for macroeconomic variables and positive/negative surprises for political/fiscal news. SU are surprise components of TB and CA shocks where available. Otherwise CA/TB are captured by dummies. See section III for details. $12 \mathrm{~m}$ : INF- and INF- lag have been excluded due to offsetting effects: $\left(\operatorname{Chi}^{2}(1)=0.05\right)$. 
Table 3: Poland: Results of the basic model

\begin{tabular}{|c|c|c|c|c|c|c|}
\hline & & $3 \mathrm{~m}$ & $12 \mathrm{~m}$ & Bonds & Zloty/euro & Stock market \\
\hline & & AGARCH & GARCH & ATGARCHM & OLS & OLS \\
\hline & Cases & Coeff. & Coeff. & Coeff. & Coeff. & Coeff. \\
\hline $\begin{array}{l}\alpha_{0} \\
\alpha_{1} \\
\beta_{0} \\
\text { student-t } \\
\text { asymmetry } \\
\text { threshold } \\
\mathrm{h}_{\mathrm{t}}\end{array}$ & & $\begin{array}{l}0.000002 \\
0.085 \\
0.915^{\star \star \star} \\
2.83 \\
0.008\end{array}$ & 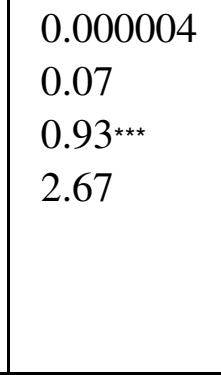 & $\begin{array}{l}0.0004^{\star \star \star} \\
0.26 \\
0.74^{\star \star \star} \\
6.22 \\
0.02^{\star} \\
-0.21^{\star \star \star} \\
-1.31^{\star \star \star}\end{array}$ & & \\
\hline $\begin{array}{l}\text { GDP lead } \\
\text { GDP lag } \\
\text { INF+ lead } \\
\text { INF+ } \\
\text { INF+ lag } \\
\text { INF- lead } \\
\text { INF- } \\
\text { INF- lag } \\
\text { CASU+ lead } \\
\text { CASU+ } \\
\text { CASU- lead } \\
\text { CASU- } \\
\text { CASU- lag } \\
\text { CA+ } \\
\text { CA- }\end{array}$ & $\begin{array}{l}12 \\
12 \\
13 \\
13 \\
13 \\
20 \\
20 \\
20 \\
19 \\
19 \\
13 \\
13 \\
13 \\
11 \\
10\end{array}$ & $-0.01^{* * *}$ & $\begin{array}{l}0.06^{\star \star \star} \\
-0.02^{\star \star \star} \\
-0.04^{\star \star} \\
-0.005^{\star \star \star} \\
0.01^{\star \star \star}\end{array}$ & $0.05^{\star}$ & $\begin{array}{l}-0.01^{\star \star} \\
-0.01^{\star \star \star} \\
-0.01^{\star \star} \\
0.01^{\star} \\
-0.003^{\star *} \\
-0.01^{\star \star \star} \\
0.00001^{\star *}\end{array}$ & $\begin{array}{l}-0.02^{\star \star} \\
-0.02^{\star \star} \\
-0.03^{\star \star \star} \\
-0.01^{\star}\end{array}$ \\
\hline $\begin{array}{l}\text { Fiscal+ } \\
\text { Fiscal- } \\
\text { Political+ } \\
\text { lead } \\
\text { Political+ } \\
\text { Political+ lag } \\
\text { Political- } \\
\text { Political- lag }\end{array}$ & $\begin{array}{l}14 \\
27 \\
25 \\
25 \\
25 \\
35 \\
35\end{array}$ & $0.01^{\text {** }}$ & $\begin{array}{c}0.01^{\star} \\
-0.01^{\star \star \star} \\
0.01^{\star \star \star}\end{array}$ & $0.03^{\star *}$ & $\begin{array}{c}0.003^{* \star} \\
0.003^{* \star \star} \\
-0.002^{\star} \\
-0.004^{\star \star \star} \\
-0.002^{* \star} \\
0.003^{* \star *}\end{array}$ & $-0.004^{\star *}$ \\
\hline \multicolumn{2}{|l|}{ No. of observations } & 720 & 720 & 720 & 720 & 720 \\
\hline \multicolumn{2}{|c|}{ Log-Likelihood } & 1785.19 & 1588.26 & 1177.12 & 2874.46 & 2198.21 \\
\hline \multicolumn{2}{|c|}{ Normality test $\left(\mathrm{Chi}^{2}(2)\right)$} & $598.7^{* \star *}$ & $1735^{\star \star \star}$ & $38.7^{\star \star \star}$ & 2.71 & 3.76 \\
\hline \multicolumn{2}{|l|}{ ARCH 1-1 test } & $\mathrm{F}(1,674)=0.80$ & $\mathrm{~F}(1,675)=0.20$ & $F(1,670)=0.02$ & $F(1,664)=0.56$ & $F(1,672)=0.73$ \\
\hline \multicolumn{2}{|l|}{ ARCH $1-2$ test } & $F(2,672)=0.512$ & $F(2,673)=0.10$ & $F(2,668)=1.36$ & $F(2,662)=0.29$ & $F(2,670)=0.69$ \\
\hline \multicolumn{2}{|l|}{ Portmanteau test } & $\operatorname{Chi}^{2}(26)=38.1^{*}$ & $\operatorname{Chi}^{2}(24)=39.2^{* *}$ & $\operatorname{Chi}^{2}(25)=19.17$ & $\operatorname{Chi}^{2}(24)=25.6$ & $\operatorname{Chi}^{2}(26)=18.01$ \\
\hline
\end{tabular}

Notes: $* * *, \quad * *, \quad$ and $*$ indicate significance at a $1 \%, 5 \%$ and $10 \%$ level. Abbreviations: AGARCH - Asymmetric GARCH, ATGARCHM - Asymmetric Threshold GARCH-inMean, INF - inflation shock, CA - current account, TB - trade balance, Fiscal - fiscal news, Political political news, +/- indicate higher/lower than expected outcomes for macroeconomic variables and positive/negative surprises for political/fiscal news. SU are surprise components of TB and CA shocks where available. Otherwise CA/TB are captured by dummies. See section III for details. $3 \mathrm{~m}$ : INF+ and INF+ lag have been excluded for offsetting effects. $\left(\mathrm{Chi}^{2}(1)=0.02\right)$. Bonds: INF- lead and INF- have been excluded for offsetting effects. $\left(\mathrm{Chi}^{2}(1)=0.11\right)$. 
balance news does not support this hypothesis as the signs of coefficients point in a different direction.

However, this outcome may simply reflect the data problems in computing current account and/or trade balance shocks. Macroeconomic news has a particularly significant influence on short-term interest rates. The significance of inflation and GDP shocks indicates that financial markets believe that monetary policy in these countries can be described by some sort of Taylor rule. Political and fiscal news is also significant and displays the expected signs. The greatest impact occurs in the case of bond spreads, which might point to longer-term effects of political news and exchange rates. These results support our main hypothesis that news related to euro adoption has a significant impact on financial markets. Consequently, this kind of news rather affects forward-looking assets, such as bonds and exchange rates since euro adoption is expected in the medium rather than short term. Stock markets are the least responsive to our news indicators, which is in line with results obtained from highly developed markets such as the US (see Pearce and Roley 1985).

Comparing the absolute impact of news on financial markets we find that Hungary is most strongly affected, with macroeconomic and political news having a similar impact. In the Czech Republic, the significance of macroeconomic news dominates, while in Poland it is the other way around. This might reflect the fact that Hungary is characterized by both a twin deficit and political uncertainty. Many Polish problems during the last three years were of a political nature, while in the Czech Republic political news was unable to overshadow the good economic fundamentals. We will continue analysing these aspects using a pooled GARCH model below. 
Importance of news

So far in this analysis, we have treated all political news as equally important. Next, we investigate the question of whether the importance of political news matters. Foreign investors especially - but also local investors - might only notice, or at least consider, the most prominent news in the CEEC-3. Therefore, our conjecture is that important news generates a greater impact on financial markets than less important news. In order to distinguish between news of primary and secondary importance we look at the position of a particular news item in the respective Country Newsletter from Interfax. If a news report is placed first in that newsletter, we consider it to be primary news; if it appears later in the newsletter, we consider it to be of secondary importance. Berger et al. (2006) constructed an intensity index to capture the quality and quantity of press coverage on ECB policy; however, in the light of our limited number of sources, this is not possible here.

We test these news categories in the framework of our control models derived above. The results are displayed in Table $4 .{ }^{24}$ Primary news is labelled $P N$ and secondary news is labelled $S N$. With the exception of the Polish stock market, important news has a relatively greater economic and statistical impact on financial markets. One explanation could be that positive transaction costs make an adjustment of portfolios worthwhile only in the case of important news. Another explanation could be that the position of a news item in the newsletter is endogenous to market movements. Hence, on particularly volatile trading days, the news agency searches for possible causes in the list of news and places the most likely candidate on the first page of the newsletter - which is published at the end of the trading day. In other words, we may be measuring the outcome of a subjective filtering process undertaken by the news agencies.

${ }^{24}$ See Tables 1-3 for diagnostic statistics.

Editorial Office, Dept of Economics, Warwick Ūniversity, Coventry CV4 7AL, UK 


\section{Table 4: Importance of news}

\begin{tabular}{|l|l|l|l|l|l|l|}
\hline & & $3 \mathrm{~m}$ & $12 \mathrm{~m}$ & Bonds & CEEC-3/€ & Stock market \\
\hline & Cases & Coeff. & Coeff. & Coeff. & Coeff. & Coeff. \\
\hline
\end{tabular}

\section{Czech Republic}

\begin{tabular}{|c|c|c|c|c|c|c|}
\hline PN- & 14 & & & $0.02^{\star \star}$ & $0.002^{\text {** }}$ & \\
\hline \multicolumn{7}{|l|}{ Hungary } \\
\hline $\begin{array}{l}\mathrm{PN}+ \\
\mathrm{PN}+\text { lag }\end{array}$ & $\begin{array}{l}14 \\
14\end{array}$ & & $-0.01^{*}$ & $-0.04^{* *}$ & $-0.003^{\star * *}$ & \\
\hline $\begin{array}{l}\text { PN- } \\
\text { PN- lag }\end{array}$ & $\begin{array}{l}41 \\
41\end{array}$ & & $\begin{array}{l}0.02^{* * *} \\
0.01^{* *}\end{array}$ & $0.04^{* *}$ & $\begin{array}{l}0.001^{*} \\
0.001^{*}\end{array}$ & \\
\hline $\mathrm{SN}+$ lead & 14 & & & & $-0.003^{\star * \star}$ & \\
\hline \multicolumn{7}{|l|}{ Poland } \\
\hline $\begin{array}{l}\mathrm{PN}+\text { lead } \\
\mathrm{PN}+\end{array}$ & $\begin{array}{l}16 \\
16\end{array}$ & $-0.009^{* * *}$ & $-0.009^{* *}$ & & & \\
\hline $\begin{array}{l}\mathrm{PN}- \\
\mathrm{PN}-\mathrm{lag}\end{array}$ & $\begin{array}{l}17 \\
17\end{array}$ & $0.006^{* \star}$ & $0.01^{\star \star \star}$ & $0.05^{\text {** }}$ & $0.004^{\star \star \star}$ & \\
\hline $\mathrm{SN}+\mathrm{lag}$ & 23 & & & & $-0.002^{*}$ & \\
\hline $\begin{array}{l}\text { SN- lead } \\
\text { SN- }\end{array}$ & $\begin{array}{l}45 \\
45\end{array}$ & $-0.004^{*}$ & 8 & & & $-0.004^{*}$ \\
\hline
\end{tabular}

Notes: $* * *, * *$, and * indicate significance at a $1 \%, 5 \%$ and $10 \%$ level. Only significant variables are included in the table. Abbreviations: PN - primary news, $\mathrm{SN}$ - secondary news.

CZ 3m: SN+ lead and SN+ have been excluded due to offsetting effects. $\mathrm{Chi}^{2}(1)=0.01$.

CZ Stock market: SN+ and SN+ lag have been excluded due to offsetting effects. $\mathrm{Chi}^{2}(1)=0.17$.

CZ 12m: Insignificant macroeconomic news had to be excluded to ensure convergence. This did not change the significance or size of coefficients in a noteworthy way.

PL 12m: SN- lead and SN- have been excluded due to offsetting effects. $\operatorname{Chi}^{2}(1)=0.13$.

PL Zloty/euro: SN- lead and SN- have been excluded due to offsetting effects. $\mathrm{Chi}^{2}(1)=1.01$.

\section{Sources of news}

Next, we address the question of whether the (primary) sources of news have implications for the impact of news on financial markets. We construct four categories of news sources. Category $(A)$ consists of news originating from financial market analysts and rating agencies. The latter especially could be of significant influence, as their assessments of a country (as a debtor) are closely watched by both private and institutional investors. 
Analysts also frequently comment on the prospects and date of euro adoption in a given country.

The second category, which contains the largest number of events, is news published by government sources $(G)$. Note that the notion of government here is fairly broad as we include, in addition to the executive, the President, parliamentary groups and party officials, if these give indications of the future course of government policy. We might expect bad news to have more credibility and therefore a greater impact than good news as usually the government has no interest in publishing bad news.

Our third category gathers announcements made by the central bank $(C B)$. Only a few events are considered as the CEEC-3 central banks do not frequently comment on the long-run prospects of euro adoption. The majority of news here is negative, which to some extent reflects tensions between government and central bank officials in the sample countries during the observation period.

The last category, international organisations $(I O)$, captures statements or recommendations issued by the European Union, the World Bank or the IMF. In the context of euro adoption, some of the decisions by the European Commission (e.g. on accounting issues such as the incorporation of Public Private Partnerships into the government budget) are important.

We use the basic control models derived above to test the impact of the sources of news and the results are displayed in Table $5 .{ }^{25}$ Contrary to our hypothesis formulated above, news originating from analysts and rating agencies has an ambiguous impact on financial markets.

An exception is the Hungarian bond market, where negative news from analysts and rating agencies leads to a significant increase in the bond spread of almost 3 basis points. In the other markets and countries, results are rather mixed.

\footnotetext{
${ }^{25}$ Note that the total number of news in Table 5 differs from those in the previous tables since some news could not be clearly assigned to one of our source categories. See Tables 1-3 for diagnostic statistics.
} 
Table 5: Sources of News

\begin{tabular}{|l|l|l|l|l|l|l|}
\hline & & $3 \mathrm{~m}$ & $12 \mathrm{~m}$ & Bonds & CEEC-3/€ & Stock market \\
\hline & Cases & Coeff. & Coeff. & Coeff. & Coeff. & Coeff. \\
\hline
\end{tabular}

\section{Czech Republic}

\begin{tabular}{|l|l|l|l|l|l|l|}
\hline G+ lead & 14 & & & $0.05^{*}$ & & \\
\hline G- & 16 & & & $0.002^{\star *}$ & \\
G- lag & 16 & & & & $0.002^{* *}$ & \\
\hline
\end{tabular}

\section{Hungary}

\begin{tabular}{|c|c|c|c|c|c|c|}
\hline $\begin{array}{l}\text { A- lead } \\
\text { A- } \\
\text { A- lag }\end{array}$ & $\begin{array}{l}23 \\
23 \\
23\end{array}$ & & $-0.01^{*}$ & $0.03^{\star \star \star}$ & $0.002^{*}$ & $-0.007^{* *}$ \\
\hline $\begin{array}{l}\mathrm{G}+ \\
\mathrm{G}+\text { lag }\end{array}$ & $\begin{array}{l}20 \\
20 \\
\end{array}$ & $\begin{array}{l}-0.007^{\star} \\
-0.01^{\star \star}\end{array}$ & $-0.02^{\star *}$ & $-0.04^{* *}$ & $-0.003^{\star \star \star}$ & \\
\hline $\begin{array}{l}\text { G- } \\
\text { G- lag }\end{array}$ & $\begin{array}{l}20 \\
20\end{array}$ & $0.02^{* *}$ & $0.04^{\star \star \star}$ & $\begin{array}{l}0.06^{* *} \\
0.03^{*}\end{array}$ & $\begin{array}{l}0.001^{\star \star} \\
0.003^{\star \star \star *}\end{array}$ & \\
\hline $\begin{array}{l}\text { CB- lead } \\
\text { CB- } \\
\text { CB- lag }\end{array}$ & $\begin{array}{l}12 \\
12 \\
12\end{array}$ & $0.03^{* *}$ & $0.03^{\star \star \star}$ & & $-0.002^{* *}$ & \\
\hline IO- & 19 & & 1 & & & $0.006^{* *}$ \\
\hline
\end{tabular}

\section{Poland}

\begin{tabular}{|c|c|c|c|c|c|c|}
\hline $\begin{array}{l}\mathrm{A}+\text { lead } \\
\mathrm{A}+ \\
\mathrm{A}+\mathrm{lag}\end{array}$ & $\begin{array}{l}5 \\
5 \\
5\end{array}$ & $\begin{array}{c}-0.007^{\star \star *} \\
0.01^{\star *} \\
-0.02^{\star *}\end{array}$ & $\begin{array}{l}0.006^{* * *} \\
-0.01^{\star \star *}\end{array}$ & $0.05^{\text {***}}$ & & \\
\hline A- lead & 6 & & $0.008^{\star *}$ & 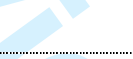 & & \\
\hline $\mathrm{G}+$ & 32 & & $-0.008^{\star \star \star}$ & 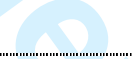 & $-0.002^{\star}$ & \\
\hline $\begin{array}{l}\text { G- lead } \\
\text { G- } \\
\text { G- lag }\end{array}$ & $\begin{array}{l}42 \\
42 \\
42\end{array}$ & $\begin{array}{r}-0.004^{*} \\
0.004^{* *}\end{array}$ & $\begin{array}{c}-0.004^{\star} \\
0.009^{\star * \star}\end{array}$ & 0.02 * & $0.003^{* * *}$ & $-0.003^{*}$ \\
\hline
\end{tabular}

Notes: $* * *, * *$, and $*$ indicate significance at a $1 \%, 5 \%$ and $10 \%$ level. Only significant categories with at least five cases are listed.

Abbreviations of news sources: A - analysts and rating agencies, G - government, CB - central banks, IO international organisations.

CZ 12m: Insignificant macroeconomic news had to be excluded to ensure convergence. This did not change the significance or size of coefficients in a noteworthy way.

HU Forint/€: Insignificant macroeconomic news had to be excluded to ensure convergence. This did not change the significance or size of coefficients in a noteworthy way.

News from international organisations mainly arises in the case of Hungary. Our results show that there is no strong impact of news issued by international organisations on financial markets. Given the results in Hayo and Kutan (2005a), this suggests that the 
'news' considered here is not a real surprise for financial markets as reports, statements and decisions announced by international institutions are often published after a long process of negotiation and deliberation.

The only country with a sizeable amount of central bank news is Hungary (12 negative news). We observe some impact on short-run interest rates and on the exchange rate, in both cases with the expected coefficients. Finally, concerning the government category, we find evidence, particularly in Hungary and Poland, for the hypothesis put forward above, whereas in the Czech Republic the impact is less pronounced. Both good and bad news tend to have an impact on financial markets. We will explore the existence of asymmetric effects in greater detail in the next subsection.

Asymmetric effects within markets

It is frequently claimed that negative news has a greater impact on financial markets than does positive news. Aggarwal and Schirm (1998) put forward three main reasons for such an asymmetric market reaction to news. First, there might be some volatility feedback, i.e. news may, in general, increase volatility and thus risk which, given constant expected returns, causes asset prices to fall. As a result the impact of negative relative to positive news is estimated as being greater. Second, asymmetries might arise from the irrational behaviour of market participants, who price downside risks higher than upside risks. Finally, it is possible that policymakers' reaction to news is asymmetric. An unexpected fall in inflation might carry less importance for a stability minded central bank than a surprising rise in inflation of equal size.

Testing for asymmetric effects of political and fiscal news within our basic model reveals that in accordance with our a priori expectations bad news has a significantly larger effect in some markets and news categories. For the Czech Republic we find that the Czech 
crown/euro exchange rate reacts more strongly to negative political news $\left(\mathrm{Chi}^{2}(1)=6.9\right)$. We observe the same for the Czech stock market $\left(\mathrm{Chi}^{2}(1)=7.4\right)$, where the effect even persists over the three-day observation window $\left(\mathrm{Chi}^{2}(1)=6.1\right)$. In contrast, in the Hungarian financial markets, there are no asymmetric effects of good and bad political or fiscal news. In Poland, the results are slightly ambiguous: while negative fiscal $\left(\mathrm{Chi}^{2}(1)=\right.$ 3.6) and political $\left(\mathrm{Chi}^{2}(1)=4.5\right)$ news has a greater impact on government bonds spread vis-à-vis their positive counterparts, ${ }^{26} 12$ month interest rates and the Polish zloty/euro exchange rate display stronger reactions to negative fiscal news $\left(\mathrm{Chi}^{2}(1)=4.9\right.$ and $\mathrm{Chi}^{2}(1)$ $=13.7)$ and to positive political news $\left(\operatorname{Chi}^{2}(1)=2.8\right.$ and $\left.\operatorname{Chi}^{2}(1)=3.1\right)$. Moreover, in both markets, the asymmetric effect in favour of positive political news is persistent over the three-day window. ${ }^{27}$

With regard to the distinction between primary and secondary news we find (weak) evidence for asymmetric effects, for both types of news. A noteworthy difference to the basic model is that the asymmetric effects are not persistent over the three-day window. ${ }^{28}$ In our analysis of news categorized by sources we concentrate the asymmetry tests on government sources, as this is the only category with a sufficient amount of both negative and positive news (see Tables 5). In the Czech Republic, we find negative news to have a significantly larger economic impact on government bond spreads and the exchange rate versus the euro $\left(\mathrm{Chi}^{2}(1)=3.7\right.$ and $\left.\mathrm{Chi}^{2}(1)=5.7\right)$. In the case of the government bond spread the asymmetry effect is persistent over the three-day window $\left(\mathrm{Chi}^{2}(1)=2.9\right)$ and amounts to 5.4 basis points.

In Hungary, negative government news has a significantly stronger effect on the foreign exchange market too $\left(\operatorname{Chi}^{2}(1)=6.9\right)$, which is, however, not persistent $\left(\operatorname{Chi}^{2}(1)=\right.$

\footnotetext{
${ }^{26}$ The Polish government bond spread also demonstrates the strongest asymmetric effects to fiscal and political news with around 3 basis points each. In other markets in the CEEC-3 asymmetric effects do not rise above 1 basis point (for spreads and interest rates) or 1 percentage point (stocks and exchange rates).

${ }^{27}$ With: $\mathrm{Chi}^{2}(1)=4.9$ (Polish zloty/euro exchange rate) and $\mathrm{Chi}^{2}(1)=4.5$ (12 month interest rate).

${ }^{28}$ The results are available upon request.
} 
0.5). The other Hungarian financial markets show no signs of asymmetric effects. In Poland, asymmetric effects only exist in the 12 month interest rate $\left(\mathrm{Chi}^{2}(1)=2.7\right)$ and are persistent over the three-day window $\left(\mathrm{Chi}^{2}(1)=2.9\right)$. Thus, the conjecture that negative government news carries more credibility is supported by these results for the Czech Republic and Hungary, but not for Poland.

The impact of news on the conditional variance

Next, we include the news items in the equation of the conditional variance in order to see whether there is an impact on markets' volatility. The hypotheses are that either news has a negative effect on volatility because new information reduces uncertainty or that (bad) news increases volatility since it can cause investors to panic and leave the market (Hayo and Kutan 2005a). However, we cannot detect any significant impact of news on volatility. This is partly due to technical problems with the models, as in many cases including the news variables in the conditional variance equation prevents the estimation algorithm from converging (see Doornik and Ooms 2008). In the remaining four models, the impact of news on the conditional variance is insignificant. This finding raises doubts about volatility feedback as an explanation for the occurrence of asymmetric effects of news within financial markets. 
Asymmetric effects across the sample countries

Finally, we statistically test for asymmetric effects of news across countries in the framework of a pooled GARCH model that allows for parameter heterogeneity (see equation (2)): $:^{29}$

$$
\begin{aligned}
\text { Returns }_{t}^{i}= & c+C Z_{S D}+H U_{S D}+\sum_{i} \sum_{r=1}^{4} \delta_{r}^{i} \operatorname{Returns}_{\mathrm{t}-\mathrm{r}}^{\mathrm{i}} \\
& +\sum_{i} \sum_{r=1}^{4} \gamma_{r}^{i} \text { Control Variables }_{\mathrm{t}-\mathrm{r}}^{\mathrm{i}}+\sum_{i} \sum_{r=-1}^{1} \phi_{r}^{i} \text { Macroeconomic News Variables }_{\mathrm{t}-\mathrm{r}}^{i} \\
& +\sum_{i} \sum_{\mathrm{r}=-1}^{1} \varphi_{r}^{i} \text { Political News Dummies } \\
\mathrm{t}-\mathrm{r} & +\eta \mathrm{h}_{\mathrm{t}}+\mathrm{u}_{\mathrm{t}}
\end{aligned}
$$

$$
\begin{aligned}
\text { with : } & \mathrm{u}_{\mathrm{t}}=\varepsilon_{\mathrm{t}} \mathrm{h}_{\mathrm{t}}^{1 / 2}, \\
& \mathrm{~h}_{\mathrm{t}}=\alpha_{0}+\alpha_{1}\left(\mathrm{u}_{\mathrm{t}-1}-\kappa_{1}\right)^{2}+\kappa_{2} \tau\left(\mathrm{u}_{\mathrm{t}-1}-\kappa_{1}\right)^{2}+\beta_{1} \mathrm{~h}_{\mathrm{t}-1}, \\
& \tau=1 \text { if } \mathrm{u}_{t-1}<\kappa_{1} \text { and zero otherwise. } \\
& \mathrm{i}=\mathrm{CZ}, \mathrm{HU}, \mathrm{PL}
\end{aligned}
$$

As in equation (1) c, $\alpha_{0}, \alpha_{1}, \beta, \delta, \phi, \varphi, \gamma, \eta, \kappa_{1}$ and $\kappa_{2}$ are parameters or vectors of parameters, $\tau$ is an indicator function and $\varepsilon_{\mathrm{t}} \mathrm{t}$-distributed with $\mathrm{v}$ degrees of freedom. $\mathrm{CZ}_{\mathrm{SD}}$ and $\mathrm{HU}_{\mathrm{SD}}$ are step dummies and should capture country fixed effects.

The result of this comparison is shown in Table 6. Country abbreviations $\mathrm{C}, \mathrm{H}$ and $\mathrm{P}$ indicate the largest, statistically significant, economic effects of each of the news categories across all financial markets in the three economies in our sample. If several

\footnotetext{
${ }^{29}$ Note, however, that in this model the procedure differs from the estimation of equation (1) insofar as the general-to-specific approach was applied to the whole model, i.e. including the news variables. Moreover, TB shocks are not included since they were not available for all countries. CA news is included only as news dummies for the same reason.
} 
letters are given for one cell in the table, then the effects were statistically indistinguishable.

While the impact of macroeconomic news (especially for inflation and GDP) is particularly strong in Hungary, political news has the most pronounced effects in both Hungary and Poland. These results may reflect the different challenges the countries were facing during the observation period. In Hungary, financial markets were focused on macroeconomic news due to the lack of nominal convergence achieved so far and the problem of the 'twin deficits'. In Poland, however, the macroeconomic situation was perceived as less of a problem. Uncertainty arose mainly from the political scene: initially

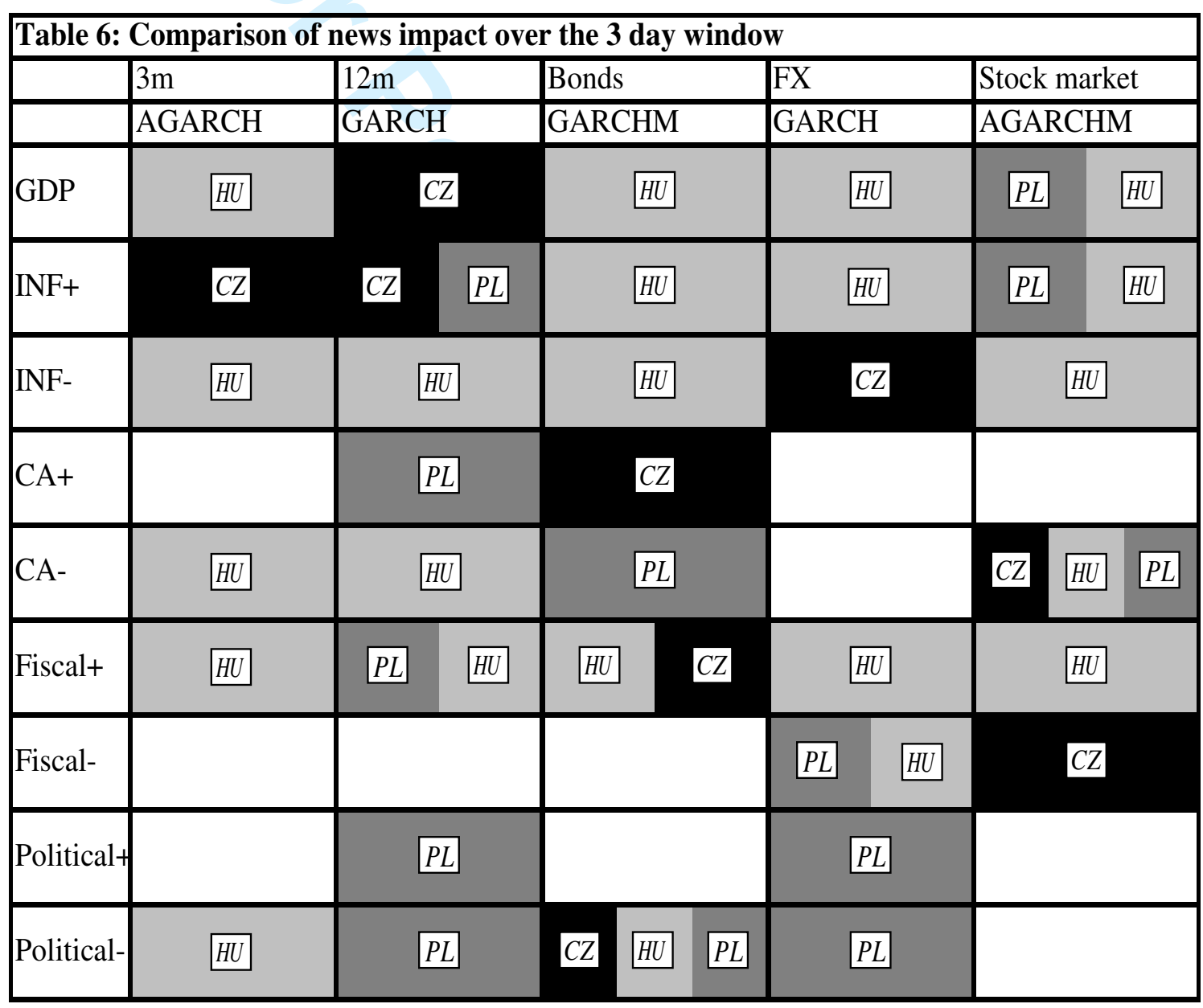

Note: Only the countries experiencing the largest significant financial market reaction are named. Abbreviations: AGARCH - Asymmetric GARCH, GARCHM - GARCH-in-Mean, AGARCHM - Asymmetric GARCH-in-Mean, CZ - Czech Republic, HU - Hungary, PL - Poland, INF - Inflation shock, CA - current account, TB - trade balance, Fiscal - Fiscal news, Political - Political news, +/- indicate higher/lower than expected outcomes for macroeconomic variables and positive/negative surprises for political/fiscal news. 


\section{Conclusions}

In this paper, we study the impact of news on financial markets in the CEEC-3 over the period 2004 to 2006 using a newly constructed and unique data set on political and macroeconomic news. The news is evaluated with respect to the integration of the CEEC-3 into the EU and the prospect of euro adoption. In an extended GARCH framework we discover that news has an impact on all financial markets, although the effects differ across markets and sample countries, reflecting the specific characteristics of the markets and the challenges the countries were facing.

Specifically, macroeconomic news tends to affect short-term interest rates, reflecting the importance of monetary policy in the short run. Kiss (2004) also finds macroeconomic news to influence short-term interest rates, although using a different empirical approach. In contrast to Hanousek et al. (2009), who use intraday data, we also find some statistically significant effects of local macroeconomic news on stock markets. 
In general, however, political and fiscal news rather affects long-term bond yields and exchange rates than stock markets.

Taken together, these results support our main hypothesis, namely that news concerning euro adoption affects financial markets in the CEEC-3 countries. Moreover, they support findings obtained by Hayo and Kutan (2005a) and Baig et al. (2006) for emerging markets as well as by Fratzscher and Stracca (2009) for a mature market. In our control model, we can confirm a claim put forward by Hanousek and Filer (2000), namely that these financial markets exhibit aspects of (weak) inefficiency, which might be indicative of either low liquidity and missing depth of these markets or market participants that do not exploit all possible information.

Furthermore, we find that the importance of a particular news item in the media source matters for the impact on financial markets. Important news as measured by visibility in news reports triggers a relatively stronger market reaction. The question of causality is unclear, however, as it is possible that the choice of news representation by the news agency is endogenous to market movements. In addition, we provide evidence that in terms of financial market impact the original source of news matters, at least to some extent. Specifically, we find that both positive and negative government announcements often cause significant movements in financial markets, whereas in our sample the impact of central banks and international organisations is limited.

We discover some evidence for asymmetric effects of news within markets and across countries. With regard to within market asymmetries, at least in the cases of the Czech Republic and Hungary, we obtain support for the stylized fact that negative news has a relatively stronger influence than positive news. At the same time, we do not find statistical evidence for an influence of these news categories on the volatility of financial markets. This makes it unlikely that these asymmetries are caused by a volatility feedback mechanism as is suggested in the literature. 
Comparing the effects of news across the CEEC-3 by means of a pooled GARCH model reveals that macroeconomic shocks have the greatest impact on Hungary, while political news has the strongest influence in Poland. Arguably, our results reflect the specific challenges the countries were experiencing during the observation period. Finally, we cannot detect any signs of strong linkages across national financial markets in the CEEC-3 sample.

To summarize, we find that news related to the possibility of euro introduction does, indeed, matter for financial markets in the CEEC-3, in spite of the fact that none of these countries is considering a swift entry into the EMU. Moreover, in general, we also present support for the hypotheses that positive news - i.e. news making an early adoption of the euro more likely - reduce the interest rate spread versus the euro area, increase share prices and strengthen the local currency, with negative news causing the opposite adjustments. 


\section{References}

Aggarwal, R. and D. C. Schirm (1998) Asymmetric impact of trade balance news on asset prices, Journal of International Financial Markets, Institutions and Money, 8, 83-100.

Andritzky, J. R., G. J. Bannister and Tamirisa, N. T. (2007) The impact of macroeconomic announcements on emerging market bonds, Emerging Markets Review, 8, 20-37.

Baig, T., M. Kumar, G. Vasishtha and Zoli, E. (2006) Fiscal and monetary nexus in emerging market economies: how does debt matter?, IMF Working Paper No. 06/184.

Berger, H., M. Ehrmann and M. Fratzscher (2006) Monetary policy in the media, ECB Working Paper No. 679.

Bollerslev, T. (1986) Generalized autoregressive conditional heteroscedasticity, Journal of Econometrics, 31, 307-327.

Bollerslev, T. (1987) A conditional heteroscedastic model for speculative prices and rates of return, Review of Economics and Statistics, 69, 542-547.

Bollerslev, T. and J. M. Wooldridge (1992) Quasi-maximum likelihood estimation and inference in dynamic models with time varying covariances, Econometric Reviews, 11, $143-172$.

Chaney, E. (2008) Assessing pacification policy in Iraq, Journal of Comparative Economics, 36, 1-16.

Doornik, J. and M. Ooms (2008) Multimodality in the GARCH regression model, International Journal of Forecasting, 24, 432-448.

Engle, R. F., D. M. Lilien and R. P. Robbins (1987) Estimating time-varying risk premia in the term structure: the ARCH-M model, Econometrica, 55, 391-407.

Engle, R. F. and V. K. Ng (1993) Measuring and testing the impact of news on volatility, Journal of Finance, 48, 749-778.

European Commission (2006) Autumn Economic Forecasts, Brussels.

Evans, M. and R. Lyons (2008) How is macro news transmitted to exchange rates?, Journal of Financial Economics, 88, 26-50.

Fratzscher, M. and L. Stracca (2009) Does it pay to have the euro? Italy's politics and financial markets under the lira and the euro, ECB Working Paper No. 1064.

Gavin, W. and R. Mandal (2001) Evaluating FOMC forecasts, Federal Reserve Bank of St. Louis Working Paper Series 2001-005C.

Glosten, L. R., R. Jagannathan and D. E. Runkle (1993) On the relation between the expected value and the volatility of the nominal excess return on stocks, Journal of Finance, 48, 1779-1801.

Gravelle, T. and R. Moessner (2001) Reactions of Canadian interest rates to macroeconomic announcements - implications for monetary policy transparency, Bank of Canada Working Paper 2001-5.

Hanousek, J. and R. K. Filer (2000) The relationship between economic factors and equity markets in central Europe, Economics of Transition 8, 623-638. 
Hanousek, J., E. Kočenda and A. Kutan (2009) The reaction of asset prices to macroeconomic announcements in new EU markets, Journal of Financial Stability, 5, 199219.

Hayo, B. and A. Kutan (2005a) IMF-related news and emerging financial markets, Journal of International Money and Finance, 24, 1126-1142.

Hayo, B. and A. Kutan (2005b) The impact of news, oil prices and global market developments on Russian financial markets, Economics of Transition, 13, 373-393.

Hendry, D. F. (1995) Dynamic Econometrics, Oxford: Oxford University Press.

International Monetary Fund (2006) Annual Report on Exchange Arrangements and Exchange Restrictions, Washington.

Joyce, M. and V. Read (1999) Asset price reactions to RPI announcements, Bank of England Working Paper 94.

Kiss, N. M. (2004) The effects of macroeconomic news on money markets, MNB Occasional Paper No 2004/30.

Kočenda E. and J. Valachy (2006) Exchange rate volatility and regime change: A visegrad comparison, Journal of Comparative Economics, 34, 727-753.

Luengnaruemitchai, P. and S. Schadler (2007) Do economists' and financial markets' perspectives on the new members of the EU differ?, IMF Working Paper 07/65.

Nelson, D. (1990) Stationarity and persistence in the $\operatorname{GARCH}(1,1)$ model, Econometric Theory, 6, 318-334.

Onder, Z. and C. Simga-Mugan (2006) How do political and economic news affect emerging markets? Evidence from Argentina and Turkey, Emerging Markets Finance and Trade, 42, 50-77.

Pearce, D. K. and Roley, V. V. (1985) Stock prices and economic news, NBER Working Paper Series, 1296. 


\section{Appendix}

\begin{tabular}{|c|c|c|c|c|c|c|c|c|}
\hline \multicolumn{9}{|c|}{ Table A1: Descriptive Statistics of daily returns (growth rates in \%) } \\
\hline & & Obs. & Mean & Std.Devn. & Skewness & $\begin{array}{l}\text { Excess } \\
\text { Kurtosis }\end{array}$ & Minimum & Maximum \\
\hline \multirow{5}{*}{ 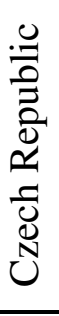 } & Bondspread & 717 & -0.0011 & 0.033 & 0.25 & 5.2 & -0.18 & 0.20 \\
\hline & Pribor $3 \mathrm{~m}$ & 717 & 0.0007 & 0.021 & -2.45 & 69.1 & -0.25 & 0.22 \\
\hline & Pribor12m & 717 & 0.0007 & 0.028 & -2.03 & 49.2 & -0.36 & 0.22 \\
\hline & PX-50 & 717 & 0.0012 & 0.011 & -0.56 & 5.1 & -0.06 & 0.07 \\
\hline & Crown/euro & 717 & -0.0002 & 0.003 & -0.11 & 1.3 & -0.01 & 0.01 \\
\hline \multirow{5}{*}{ 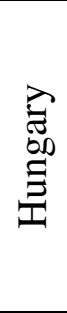 } & Bondspread & 726 & -0.0014 & 0.083 & 0.86 & 5.6 & -0.31 & 0.62 \\
\hline & Bubor3m & 726 & -0.0058 & 0.075 & 1.28 & 34.1 & -0.62 & 0.83 \\
\hline & Bubor12m & 726 & -0.0041 & 0.104 & 0.50 & 24.8 & -0.86 & 0.84 \\
\hline & BUX & 726 & 0.0013 & 0.014 & -0.21 & 1.0 & -0.06 & 0.05 \\
\hline & Forint/euro & 726 & -0.0001 & 0.005 & 0.50 & 2.8 & -0.02 & 0.03 \\
\hline \multirow{5}{*}{$\begin{array}{l}\overparen{D} \\
\frac{\pi}{0} \\
0\end{array}$} & Bondspread & 725 & -0.0012 & 0.055 & 0.59 & 4.3 & -0.20 & 0.39 \\
\hline & Wibor3m & 725 & -0.0018 & 0.036 & 2.12 & 38.4 & -0.24 & 0.44 \\
\hline & Wibor $12 \mathrm{~m}$ & 725 & -0.0017 & 0.045 & 0.54 & 9.7 & -0.27 & 0.25 \\
\hline & WIG20 & 725 & 0.0010 & 0.013 & -0.29 & 1.5 & -0.06 & 0.05 \\
\hline & Zloty/euro & 725 & -0.0003 & 0.005 & 0.17 & 1.0 & -0.02 & 0.02 \\
\hline
\end{tabular}

Notes: PX-50, BUX and WIG20 are the main local stock indices. Pribor, Bubor and Wibor are the respective interbank money market offered rates.

Sources: National central banks, Eurostat, www.money.pl, www.pse.cz, Yahoo.com, www.cbonds.info. 


\begin{tabular}{|l|l|rrr|l|}
\hline \multicolumn{7}{|l|}{ Table A2: Overview of News Data } \\
\hline & Type & CZ & Hun & Pol & Sources \\
\hline CB+ & $25 / 50 / 75^{*}$ & 5 & 5 & 3 & Central Banks \\
CB- & $-25 /-50 /-75^{*}$ & 3 & 16 & 7 & Central Banks \\
CBSU+ & dummy & 3 & 2 & 4 & Interfax Business Reports \\
CBSU- & dummy & 2 & 5 & 3 & Interfax Business Reports \\
GDP & shock +/- & 10 & 9 & 12 & Consensus Forecasts, Statistical Offices, CB \\
INF+ & shock + & 14 & 16 & 13 & Consensus Forecasts, Statistical Offices, CB \\
INF- & shock - & 17 & 11 & 20 & Consensus Forecasts, Statistical Offices, CB \\
CASU+ & dummy & 12 & 9 & 19 & Interfax Business Reports, Statistical Offices, CB \\
CASU- & dummy & 13 & 5 & 13 & Interfax Business Reports, Statistical Offices, CB \\
CA+ & shock + & 7 & $* *$ & 11 & Interfax Business Reports, Statistical Offices, CB \\
CA- & shock - & 8 & $* *$ & 10 & Interfax Business Reports, Statistical Offices, CB \\
TBSU+ & dummy & 18 & 20 & $* * *$ & Interfax Business Reports, Statistical Offices, CB \\
TBSU- & dummy & 11 & 13 & $* * *$ & Interfax Business Reports, Statistical Offices, CB \\
TB+ & shock + & 10 & 13 & $* * *$ & Interfax Business Reports, Statistical Offices, CB \\
TB- & shock - & 9 & 9 & $* * *$ & Interfax Business Reports, Statistical Offices, CB \\
F+ & dummy & 10 & 12 & 14 & Interfax Business Reports \\
F- & dummy & 8 & 41 & 27 & Interfax Business Reports \\
P+ & dummy & 7 & 16 & 25 & Interfax Business Reports \\
P- & dummy & 16 & 34 & 35 & Interfax Business Reports \\
\hline
\end{tabular}

Notes: *changes of the reference rate in basis points.

** after sept 04 just quarterly data.

*** lack of data on expectations.

Abbreviations: CB captures interest rate changes by the central bank, CBSU indictase whether the decision has been a surprise or not, INF - inflation shock, CA - current account, TB - trade balance, Fiscal - fiscal news, Political - political news, +/- indicate higher/lower than expected outcomes for macroeconomic variables and positive/negative surprises for political/fiscal news. SU are surprise components of TB and CA shocks where available. Otherwise CA/TB are captured by dummies. See section III for details. 


\begin{tabular}{|c|c|c|c|c|c|}
\hline \multicolumn{6}{|c|}{ Table A3: Overview of Macroeconomic shocks } \\
\hline & & No of cases & Average & Minimum & Maximum \\
\hline \multirow{7}{*}{ 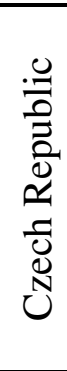 } & GDP & 10 & 0.44 & -0.4 & 2.1 \\
\hline & INF+ & 14 & 0.21 & 0.1 & 0.5 \\
\hline & INF- & 17 & 0.32 & 0.1 & 1.7 \\
\hline & $\mathrm{CA}+$ & 7 & 1.86 & 0.2 & 3.0 \\
\hline & CA- & 8 & 9.36 & 2.3 & 17.0 \\
\hline & $\mathrm{TB}+$ & 10 & 3.75 & 1.0 & 11.2 \\
\hline & TB- & 9 & 2.90 & 0.7 & 5.8 \\
\hline \multirow{5}{*}{ 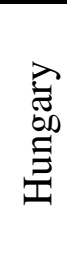 } & GDP & 9 & 0.02 & -0.7 & 1.0 \\
\hline & INF+ & 16 & 0.29 & 0.1 & 1.1 \\
\hline & INF- & 11 & 0.24 & 0.1 & 0.6 \\
\hline & $\mathrm{TB}+$ & 13 & 90.94 & 15.5 & 237.7 \\
\hline & TB- & 9 & 54.81 & 20.0 & 93.2 \\
\hline \multirow{5}{*}{ 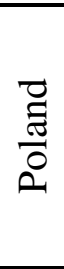 } & GDP & 12 & 0.02 & -1.1 & 1.1 \\
\hline & INF+ & 13 & 0.39 & 0.1 & 1.0 \\
\hline & INF- & 20 & 0.28 & 0.1 & 0.5 \\
\hline & $\mathrm{CA}+$ & 11 & 341.95 & 50.0 & 561.0 \\
\hline & CA- & 10 & 338.30 & 43.0 & 996.0 \\
\hline
\end{tabular}

Notes: CA/TB shocks are denominated in billions (CZ, HUN) or millions (PL) of local currency, GDP/Inflation shocks in percentage points. 